月田細胞軸プロジェクト中間評価報告書

評価委員

石川春律 野田哲生 宮園浩平
群馬大学医学部 教授

東北大学医学部 教授 ((兼) (財) 癌研究会癌研究所 部長)

(財) 癌研究会癌研究所 部長

1. 研究の進捗状況と今後の見込み

\title{
1.1. 全体の評価
}

月田細胞軸プロジェクトは、分子細胞生物学領域において今日急速に関心が高まってい る「細胞極性」の問題を「細胞軸」という本質から捉えようとする挑戦的な計画のもとに 組織された。生体の基本単位である細胞が示す生命活動の多くは細胞軸に沿って整然とな されている。「細胞軸の本体は何か」という未解明の課題に対しては研究の手がかりとなる 「種探し」から始めなければならない。本プロジェクトでは総括責任者が備えている形態 学の基礎をもとに、分子生物学をはじめとする新しい研究方法を駆使して、光の「種探し」 をしようとする点が最大の特色であり、世界的にも独創的な研究といえる。本プロジェク トが ERATO の一つの事業として実現したことにまず敬意を表したい。

本プロジェクトは、「細胞軸」を蛋白輸送軸、細胞分裂軸、および形態形成軸という3つ

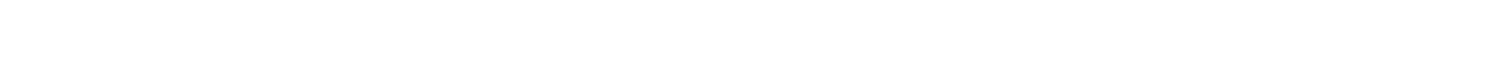
されている。3つの研究グループはバランスがよく、若い研究者をリーダーとし、興味深 い具体的テーマを掲げ、極めて積極的に取り組んでいることが高く評価される。プロジェ クト開始からわずか 3 年ですでにいくつかの「種」が見出されている。評価者光れ光れの 意見はほぼ一致したものであったので、ここに統一見解として報告する。

\section{2. 研究構想の具体化状況}

本プロジェクトは3つの研究グループから組織されている。(1) 蛋白輸送軸グループでは 蛋白質分泌の軸を探る方向の研究、(2)細胞分裂軸グループでは中心体構造と機能を探る方 向、および (3) 形態形成軸グループでは細胞間接着という観点から探る方向の研究を具体 的なテーマとして研究が開始され、現在進行中である。本プロジェクトの基本方針として、 $「$ 種探し」に重点を置いた研究活動がなされ、すでにいくつかの「種」が見出され、部分 的に「芽」の創出さえ見えてきている。以下に各研究グループの活動状況についての評価 を述べる。 
(1)蛋白輸送軸グループ

このグループでは、グループリーダーを中心として、小胞体で合成された蛋白質の細胞内 輸送に関与する蛋白質探索を、酵母を用いて行っている。光の結果、新規のストレス蛋白 質が発見され、光の機能について遺伝子破壊実験で検証を進めている。また、蛋白質の折 りたたみ（folding）を制御する新たな蛋白質アンフォルジン（unfoldin）をクローニングし、 精製し、その性質を詳細に検討し、きわめて興味深い結果を得ている。アンフォルジンは、

蛋白質の高次構造破壊 (unfolding) 因子である。プロジェクト開始からわずか 3 年でこれ ほど画期的な成果が得られたことは特筆すべきである。アンフォルジンが直接蛋白質の unfolding に関わっているのか、あるいは何らかの別の作用を介しているのかは慎重に検討 すべき問題であるが、グループリーダーは光の点を十分に考慮に入れて研究を進めている 点でも高く評価できる。「種探し」が基本にあるとしても、決して大きくないグループで 4 つの研究テーマが同時進行している点で、進捗状況によっては少しテーマを絞ってもよい のではないかという印象も受けた。

(2)細胞分裂軸グループ

このグループでは、グループリーダーを中心として、単離した中心体に対する抗体を多数 作製し、これらを用いて中心体局在蛋白質の同定を進めている。光の結果として PCM 顆粒 という新たな細胞内小器官を見い出した点が注目される。この顆粒は微小管上を動いて中 心体に集積する。抗体を用いた研究は総括責任者の得意とする手法であろうが、今回はこ れを中心体の研究に応用した点が特筆される。グループリーダーはすでに中心体を認識す る数多くの抗体を得ていることから、これらの抗原を同定する研究を十分な時間と人手を 使って行ったら、大きな研究の発展が期待されるという印象を持つ。

また、がん抑制遺伝子産物である APC 蛋白質が培養細胞の突起部の微小管に特異的に濃 縮する像を示した研究員の研究も高く評価される。APC が細胞の増殖や分化などに極めて 重要な蛋白質であることはいうまでもないが、このプロジェクトにおいて APC の細胞内で の局在が明らかにされ、細胞極性形成と関係した新たな機能を示唆した点で、「種」をまく という本プロジェクトの目的に合致している。今後のさらなる発展を期待したい。

(3)形態形成軸グループ

このグループでは、グループリーダーを中心として、細胞接着蛋白質である $\mathrm{DE}$ カドヘリ ンを中心に关の機能や構造の解析を行っている。DE カドヘリンはクローニングがきわめて 困難だった遺伝子で、これをクローニングしたグループリーダーが、新たな視点からこれ をさらに発展させようとしている姿勢は評価できる。とくに卵細胞の形成時におけるカド ヘリンの動きを経時的に観察した実験、およびカドヘリンやカテニン分子内の形態形成関 与ドメインを明らかにするレスキュー実験は興味深い。また気管の形態形成の研究もショ ウジョウバエを用いた研究の利点を十分に活用したもので、今後の発展が期待される。 
PCCD という新たに見出した機能ドメインが脊椎動物を含む脊索動物のカドヘリンには存 在しないことを明らかにしたが、これがどの程度カドへリンの作用に重要かはまだ明らか ではない。唯一の不安な点として、こうしたドメインの詳細な解析は研究者にとっては興 味深いものであろうが、あまり時間を費やし過ぎると研究が小さくまとまってしまうとい う懸念を表明したい。グループとして 4つの研究テーマが同時進行しているので、㫕れら の研究が大きく発展することを期待する。

\section{3. 未踏の課題への挑戦状況}

「細胞軸」という観点はまだ新しく、全体像が見えない現時点で、乥れを主題に取り組 むこと自体果敢な挑戦といえる。賢明なことは、この課題に対して「種探し」という基本 的考え方で取り組んでいることであろう。关の結果、若い研究者が自由な発想で、討論を 重ねながら試行錯誤的に取り組むことができたと思われる。実際、すでにいくつかの「種」 が見出され、副次的な大きな発見もあり、将来にわたって取り組むべき大きな研究課題が いくつも提示されつつある。

\section{4. 研究者の参集状況}

総括責任者の方針で、若いグループリーダーが置かれ、研究員がむしろ少なく、技術員 が多く配置されたことはユニークで注目に值する。このような若い研究者の自由な発想が 直ちに試行される研究体制は通常の研究ではリスクも考えられるが、「種探し」を目的とす る本プロジェクトでは当を得たものであり、実際、人材選考も見事に成功しているといえ る。「産」「官」「学」「海外」の研究者が集まって研究をしている点でもバランスの取れた 構成であり、研究自体も新たなメンバー構成でスタートしたとは思えないほど順調に進ん でいる。ともかく、年齢的には若い研究者が、慎重にかつ大胆に研究を計画し遂行してい る点が印象的である。

\section{5. 施設・設備の整備状況}

情報関係設備も含めて研究施設は十分に整備されている。とくに、本プロジェクトに必 須と考えられるイメージング関連機器がプロジェクト全体の共同設備としてよく整備され、 活用されている点か評価できる。

\section{2 . 研究成果の現状と今後の見込み}

本プロジェクトでは、「細胞軸」について研究が進められているが、細胞軸決定が何時ど のような外的刺激、内的情報によってなされるかが本質的な研究課題になると思われる。 とくに、細胞内における情報の実体ないし分子機構の手がかりを得る、いわゆる「種探し」 に向けた研究がなされている。この目的に向かって、総括責任者および 3 人のグループリ ーダーを中心にこれまでの研究を発展させる形で新たなプロジェクトに挑み、ユニークな 
研究体制で、最適な材料を選び、高度で巧みな研究手技を用い、すでに興味深い成果を挙 げつつあることは高く評価されるべきである。このプロジェクトがスタートしてまだ 3 年 であるということやプロジェクトの主旨を考えると、論文の数やこれまでの成果について こだわる必要は現時点ではあまりないと思う。しかし、研究成果として「種」となりうる 新規の蛋白質がいつかすでに発見され、光れらの「種」は論文として公表されたり、論 文投稿中、準備中である。また、「芽」として展開が進みつつあるものもある。

\section{3 . 結語}

以上のとおり、本プロジェクトは、中間時点ですでに興味深い成果を挙げつつあり、高 く評価された。本プロジェクトは将来新しい科学の流れとなる「種」をまくことが第一の 目的であるので、小さくまとまらないように、さらに発展していくことを期待したい。本 プロジェクトでこれまで見出された「種」の一部は緊急に詳細な分析を進める必要がある と考えられるが、本プロジェクトの主旨とどう折り合いをつけるか興味がある。可能であ れば、このプロジェクトにさらに予算を加え、また一部の研究については 5 年を超えて支 援できれば、本プロジェクトの意義はさらに大きくなるのものと思われる。以上、本プロ ジェクトの研究が順調に進行していることを評価しつつ、今後の発展・展開を楽しみに見 守りたい。

以上 